\title{
Flag Leaf Photosynthesis and Stomatal Function of Grain Sorghum as Influenced by Changing Photosynthetic Photon Flux Densities
}

\author{
H. Arnold Bruns \\ USDA-ARS Crop Production Systems Research Unit, Box 350, Stoneville, MS 38776, USA \\ Correspondence should be addressed to H. Arnold Bruns; arnold.bruns@ars.usda.gov
}

Received 22 August 2016; Revised 26 October 2016; Accepted 5 December 2016

Academic Editor: Daryl Bowman

Copyright (C) 2016 H. Arnold Bruns. This is an open access article distributed under the Creative Commons Attribution License, which permits unrestricted use, distribution, and reproduction in any medium, provided the original work is properly cited.

\begin{abstract}
Photosynthesis $(A)$ and stomatal function research in grain sorghum (Sorghum bicolor (L.) Moench) is limited compared to other crops. Flag leaves from three plants of two hybrids, grown with added $\mathrm{N}$-fertilizer of $0.0,112$, and $224 \mathrm{~kg} \mathrm{ha}^{-1}$ near Elizabeth, MS, were measured for $A$ and stomatal functions at growth stages GS6 and GS7. A Li-Cor LI-6400XT set at $355 \mu \mathrm{mol}\left[\mathrm{CO}_{2}\right]$, a flow rate of $500 \mu \mathrm{mol} \mathrm{s}^{-1}$, and a 6400-02 LED light source were used to collect data. Light levels were initially set at $2200 \mu \mathrm{mol} \mathrm{m}{ }^{-2} \mathrm{~s}^{-1}$ indicated photosynthetic photon flux density (PPFD), $A$ was allowed to stabilize, data was recorded, indicated PPFD level was reduced by $200 \mu \mathrm{mol} \mathrm{m}^{-2} \mathrm{~s}^{-1}$, and the process was repeated to a level of $200 \mu \mathrm{mol} \mathrm{m}{ }^{-2} \mathrm{~s}^{-1}$. At GS6 all data were unaffected by Nfertility, hybrids, or years. Data on $C_{i}$ at GS6 indicated $A$ declines faster with decreasing PPFD than $g_{s}$. Intrinsic water use efficiency (IWUE) data supports prior research showing stomata function more to regulate water loss and only marginally limit $A$. Nitrogen fertility was null on $A$ and stomatal functions and minimal on yield; thus no attempt was made to correlate yield with these data.
\end{abstract}

\section{Introduction}

Grain sorghum is a minor crop in the lower Mississippi River Valley though more of it is grown in this region of the United States than most of the rest of the country except for the western Great Plains [1]. Estimates show that about 140,000 ha was planted in Arkansas, Louisiana, and Mississippi in 2015. Due to its relatively small hectarage compared to corn (Zea mays L.), soybean (Glycine max (L.) Merr.), and cotton (Gossypium hirsutum L.) it has never received the attention in agronomic research activities that these other crops have. University led hybrid tests on grain sorghum are reported yearly by Arkansas and Louisiana and more recently by Mississippi. Referred scientific journal articles from the Midsouth on grain sorghum though are very limited. Bruns [2] recently reported on the effects that hybrids, row types, seeding rates, and irrigation versus dryland conditions have upon grain sorghum yields in the Mississippi Delta. Heatherly et al. [3] earlier noted that grain sorghum had the least increase in economic return due to irrigation versus dryland production when compared to corn and soybean, grown in a rotation system involving these three crops. Wesley et al. [4] observed grain sorghum yields, when grown in rotation with either cotton or soybean, did not exhibit the yield decreases found in grain sorghum monocrop systems primarily due to Johnson grass (Sorghum halepense) infestations in the continuous grain sorghum. They also observed no yield differences in grain sorghum between conventional tillage systems compared to deep tillage that included subsoiling each fall.

Research on photosynthesis $(A)$ and stomatal function in grain sorghum has not been as extensive as with other crops. Like corn, sugar cane (Saccharum officinarum L.), and Bermuda grass (Cynodon dactylon L.), grain sorghum fixes $\mathrm{CO}_{2}$ by the $\mathrm{C} 4$ pathway described in detail by Hatch and Slack [5]. In the Asian subcontinent of India Subramanian et al. [6] observed $A$ decreased both before anthesis and during grain filing in rain fed grain sorghum when PPFD exceeded $1300 \mu \mathrm{mol} \mathrm{m}^{-2} \mathrm{~s}^{-1}$. Leaf water potential and $g_{s}$ decreased with increasing PPFD. Prasad and Djanaguiraman [7] observed an $8 \%$ decrease in chlorophyll content and a $22 \%$ decrease in $A$ in grain sorghum leaves of plants grown in a controlled 
environmental facility and exposed to $32^{\circ} / 28^{\circ} \mathrm{C}$ day/night temperatures $40 \mathrm{~d}$ after seeding compared to plants exposed to $32^{\circ} / 22^{\circ} \mathrm{C}$ day/night temperatures throughout the experiment. In a shade recovery study Fay and Knapp [8] observed the mean preshade $A$ level at $1700 \mu \mathrm{mol} \mathrm{m}^{-2} \mathrm{~s}^{-1}$ PPFD to be $50 \mu \mathrm{mols} \mathrm{CO}_{2} \mathrm{~m}^{-2}$ leaf area $\mathrm{s}^{-1}$. An immediate large reduction in $A$ ( $<20.0 \mu \mathrm{mols} \mathrm{CO}_{2} \mathrm{~m}^{-2}$ leaf area $\left.\mathrm{s}^{-1}\right)$ occurred when shading was imposed, reducing PPFD to $300-400 \mu \mathrm{mol} \mathrm{m}^{-2} \mathrm{~s}^{-1}$. A corresponding increase in $C_{i}$, a gradual reduction in $g_{s}$, a reduced $E_{m}$, and IWUE were also noted.

Light response curves of field grown grain sorghum to changing PPFD levels is not readily available, particularly for plants grown in a humid subtropical environment such as in the lower Mississippi River Valley. The objectives of this experiment were to measure the changes in $A, g_{s}, E_{m}, C_{i}$, and IWUE of commercially available grain sorghum hybrids at the reproductive growth stages of anthesis (GS6) and midkernel filling (GS7) as defined by Vanderlip and Reeves [9].

\section{Methods and Materials}

The study was part of a four-replication field experiment conducted during the 2014 and 2015 growing seasons. Two commonly grown grain sorghum hybrids, Pioneer brand 83P17 (Pioneer-DuPont, Johnston, IA) and DeKalb brand DKS54-03 (Monsanto, St. Louis, MO), were selected for this study. Location of the study was on privately owned land $3 \mathrm{k}$ north of Elizabeth, MS, and leased by the USDA-ARS Crop Production Systems Research Unit of the Jamie Whitten Delta States Research Center in Stoneville, MS. The site was a Tunica clay soil (clayey over loamy, montmorillonitic, nonacid, thermic, Vertic Halaquept) and prepared for planting each year by being disked level each autumn followed by the forming of $30 \mathrm{~cm}$ high ridges, spaced $102 \mathrm{~cm}$ apart in late winter. Prior to seeding the ridges were harrowed to form a $40 \mathrm{~cm}$ wide seedbed in which to plant. Seeding at a rate of 98,000 kernels $\mathrm{ha}^{-1}$ was accomplished using a John Deere model 7100 vacuum planter (John Deere, Inc., Moline, IL) and occurred on 27 May 2014 and 4 June 2015.

Approximately $21 \mathrm{~d}$ following seeding, N-fertility treatments in the form of a urea : $\mathrm{NH}_{4} \mathrm{NO}_{3}$ solution were applied at rates of $112 \mathrm{~kg} \mathrm{Nha}^{-1}$ and $224 \mathrm{~kg} \mathrm{Nha}^{-1}$ on randomly assigned whole plots. A $0 \mathrm{~kg} \mathrm{~N}^{-1}$ control was also included in the randomization of treatments. Nitrogen is considered ephemeral under the environmental conditions of the Lower Mississippi River Valley. By spring, seldom will any previously applied $\mathrm{N}$ be present due to the humid subtropical environment that allows volatilization during the winter due to waterlogged soils, leaching, and/or continuous biological denitrification as a result of soil temperatures never getting below $4.5^{\circ} \mathrm{C}$ [10]. Irrigation was unnecessary in 2014 due to frequent rainfall events, but in 2015 irrigation was applied, beginning $10 \mathrm{~d}$ following planting and two more times during the season (15 July and 4 August) to reduce drought stress. Irrigation was accomplished using a furrow system with each irrigation event applying approximately $25 \mathrm{~mm}$ of water. Weather data were acquired at an official weather reporting station managed by Mississippi State University's
Delta Research and Extension Center at Stoneville, MS, approximately $1.5 \mathrm{~km}$ from the experimental site [11].

Physiological parameters of $A, g_{s}, E_{m}, C_{i}$, and IWUE were evaluated on the two hybrids when the plants were at GS6 (anthesis) and GS7 (milk to early dough). Measurements were made on intact flag leaves of three randomly selected plants from each plot. Flag leaves were measured because they are the youngest and closest source leaf, of the developing grain. Data collection at GS6 occurred on 14 July 2014 and 30 July 2015. For GS7, data collection occurred on 19 August 2014 and 24 August 2015. Data were accumulated using a Li-Cor LI-6400XT Portable Photosynthesis System (LiCor Biosciences; Lincoln, NE) equipped with a 6400-02(B) LED light source. All data were collected between 08:30 h and $11: 30 \mathrm{~h}$ CST on days with $\leq 33.0 \%$ cloud cover to avoid presampling stomatal closure due to low natural PPFD levels. The number of samples collected was also constrained by having to allow sufficient light levels in the morning to assure maximum stomatal opening along with the leaf surface being free of dew. All measurements were completed before the mid-day decline in $A$ that is known to occur in the sorghum species $[12,13]$.

The cuvette of the instrument allowed for a $0.6 \mathrm{~cm}^{2}$ leaf surface area to be sampled. Leaf temperatures at sampling were allowed to be ambient and averaged approximately $32.5^{\circ} \mathrm{C}$. Leaf chamber $\mathrm{CO}_{2}$ levels were controlled using a $12 \mathrm{~g}$ compressed $\mathrm{CO}_{2}$ cartridge and a fixed flow rate of $500 \mu \mathrm{mol} \mathrm{s}^{-1}$. Reference $\left[\mathrm{CO}_{2}\right]$ within the leaf chamber was fixed at $355 \mu \mathrm{mol} \mathrm{mol}{ }^{-1}$, the mean atmospheric $\mathrm{CO}_{2}$ level for the region as determined at the initiation of the experiment. Light levels, generated by the LED source, were initially set at an indicated $2200 \mu \mathrm{mol} \mathrm{m}^{-2} \mathrm{~s}^{-1}$ PPFD to adequately represent full sunlight. Light response curves were generated for each flag leaf by attaching the cuvette midway along each leaf, allowing the $A$ reading to stabilize at $2200 \mu \mathrm{mol} \mathrm{m}^{-2} \mathrm{~s}^{-1}$ PPFD which was $\approx 90 \mathrm{~s}$ then decreasing indicated light levels by $200 \mu \mathrm{mol} \mathrm{m}{ }^{-2} \mathrm{~s}^{-1}$ PPFD increments, allowing readings to again stabilize $(\approx 30 \mathrm{~s})$, until an indicated level of $200 \mu \mathrm{mol} \mathrm{m}^{-2} \mathrm{~s}^{-1}$ PPFD was achieved. This procedure for curve development was used to avoid the sudden decrease in $A$ due to shading as noted by Fay and Knapp [8]. Mean $A, g_{s}, E_{m}, C_{i}$, and IWUE were calculated from the three flag leaves sampled. Data across years for both growth stages were combined and analyzed using the PROC MIXED procedure of the Statistical Analysis System 9.4 (SAS Institute, Cary, NC). Regression analyses were performed on the data collected versus PPFD levels as well as any significant interactions of year, hybrid, and N-fertility level with the PPFD levels. Trend lines were determined for each regression analysis along with the corresponding model that best explained the results.

\section{Results and Discussion}

Environmental conditions between data collection at GS6 and data collection at GS7 differed considerably among the two years [11]. Total precipitation during this period in 2014 was $123.7 \mathrm{~mm}$ compared to only 4.8 ha $\mathrm{mm}$ in 2015 and an 


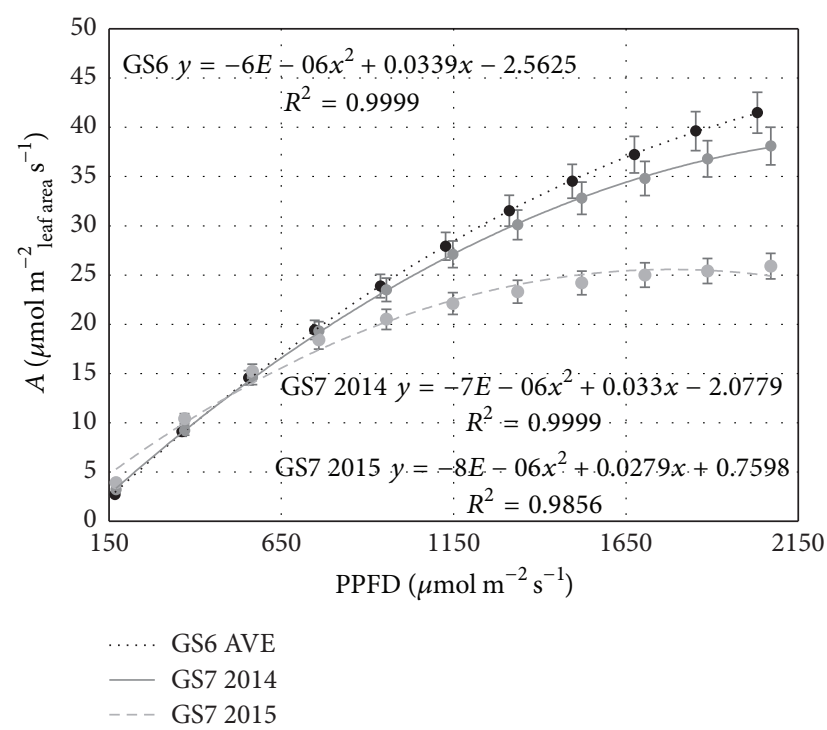

Figure 1: Mean Flag Leaf $A$ at Growth Stage 6 and Growth Stage 7 in 2014 and 2015 of grain sorghum at decreasing PPFD grown on a Tunica clay soil near Elizabeth, MS, at three levels of N-fertilizer $\left(0,112\right.$, and $\left.224 \mathrm{~kg} \mathrm{~N} \mathrm{ha}^{-1}\right)$. Means for GS6 are of three plants, two hybrids (83P17 and DKS54-03), two years (2014 \& 2015), and three $\mathrm{N}$-fertility treatments. For GS7 means are separated by year. Mean error bars set at $P \leq 0.05$.

irrigation of $25.0 \mathrm{~mm}$ applied 4 August. In 2014 waterlogged conditions of the clay soil were observed during the last $96 \mathrm{~h}$ of a major rain event beginning $1 \mathrm{~d}$ after data collection at GS6 (15 July through 21 July 2014). Such conditions are known to result in denitrification of these soils with a resulting loss of $\geq 80.0 \%$ of available $\mathrm{N}$ needed for grain development in just a matter of 72 to $96 \mathrm{~h}$ [14].

Mean maximum and minimum air temperatures during these two sampling periods were $31.0^{\circ} \mathrm{C}$ and $20.3^{\circ} \mathrm{C}$ in 2014 compared to $33.6^{\circ} \mathrm{C}$ and $21.9^{\circ} \mathrm{C}$ in 2015 . Included during this period in 2015 were two days, 7 and 9 August, which had maximum temperatures of $37.5^{\circ} \mathrm{C}$. Maximum temperatures on the days of data collection were $30.5^{\circ} \mathrm{C}$ and $32.7^{\circ} \mathrm{C}$ in 2014 and 2015, respectively. Irrigation was limited in 2015 due to equipment sharing and an unexpected equipment breakdown during peak demand.

Nitrogen fertility rates had no significant effect on mean $A$ at GS6 across both hybrids and years at all PPFD levels. It was also determined that at GS6 a quadratic equation best described the decline in $A$ as PPFD levels were reduced (Figure 1). Seeding in 2014 had acquired $\geq 1800$ adjusted growing degree units at base $10^{\circ} \mathrm{C}$ (GDU 10) by GS6 and $\geq$ 1600 GDU 10 in 2015 [11]. The 2015 seeding had also been exposed twice ( 30 and 31 July) to $\geq 37.5^{\circ} \mathrm{C}$ within $96 \mathrm{~h}$ of data collection at GS6, but $A$ rates appear unaffected as evidenced by these data.

Data for $A$ at GS7 were observed to have some significant interactions that were not observed at GS6. Mean $A$ rates for DKS54-03 were not significantly different from those of $83 \mathrm{P} 17$ in 2014 . However in 2015, A was significantly $(P \leq 0.05)$ greater across all PPFD levels above $600 \mu \mathrm{mol} \mathrm{m}^{-2} \mathrm{~s}^{-1}$ for DKS54-03 than those of 83P17. The

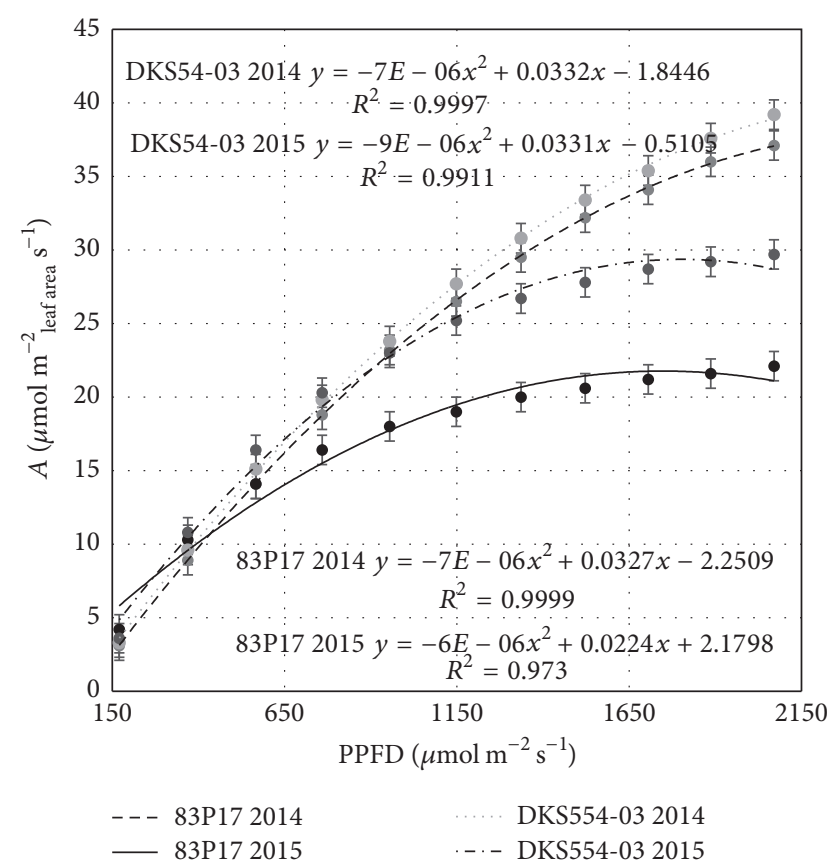

FIgURE 2: Mean Flag Leaf $A$ at Growth Stage 7 of two grain sorghum hybrids (83P17 and DKS54-03) with decreasing PPFD grown on a Tunica clay soil near Elizabeth, MS, at three levels of added Nfertilizer $\left(0,112\right.$, and $\left.224 \mathrm{~kg} \mathrm{~N} \mathrm{ha}^{-1}\right)$ in 2014 and 2015. Means of three plants and three $\mathrm{N}$-fertility treatments. Mean error bars set at $P \leq$ 0.05 .

mean A's between years across PPFD levels were also significantly $(P \leq 0.05)$ less in 2015 than 2014 for PPFD levels $>1200 \mu \mathrm{mol} \mathrm{m}^{-2} \mathrm{~s}^{-1}$ for both hybrids (Figure 2). Maximum $A$ at GS7 for both years was observed at an indicated $2200 \mu \mathrm{mol} \mathrm{m}^{-2} \mathrm{~s}^{-1}$ PPFD level. However, in 2014 mean $A$ at that level of PPFD was $38.1 \mu \mathrm{mol} \mathrm{CO}^{2} \mathrm{~m}^{-2}$ leaf area $\mathrm{s}^{-1}$ compared to $25.9 \mu \mathrm{mol} \mathrm{CO} \mathrm{m}^{-2}$ leaf area $\mathrm{s}^{-1}$ in 2015. Denitrification that likely occurred between GS6 and GS7 in 2014, as previously discussed, had no effect on $A$ according to these data (Figures 1 and 2).

A high probability of drought stress in 2015 due to a shortage of rainfall and irrigation combined with the higher temperatures observed between GS6 and GS7 best explains the lower $A$ rates observed at most PPFD levels that year compared to those of 2014. These two stresses would have caused a denaturing of some RuDPCase and other enzymes essential for $A$, interfered with stomatal conductance, and lowered turgor of the leaves thus reducing the intercellular spaces of the mesophyll to make contact with available $\mathrm{CO}_{2}$ and thus impair $A$. These observations are supported by findings reported by Subramanian et al. [6]. Peng et al. [15] also observed lower $A$ levels at $\geq 1800 \mu \mathrm{mol} \mathrm{m}^{-2} \mathrm{~s}^{-1}$ PPFD in nonirrigated grain sorghum hybrids between GS3 and GS6 compared to the same hybrids grown using trickle irrigation.

Stomatal conductance at GS6 was not found to be significantly different among $\mathrm{N}$-fertility rates, hybrids, or years. At GS6 a linear relationship best fits the response of $g_{s}$ to declining PPFD (Figure 3). Stomatal conductance at GS7 was significantly $(P \leq 0.01)$ less at all PPFDs in 2015 than 


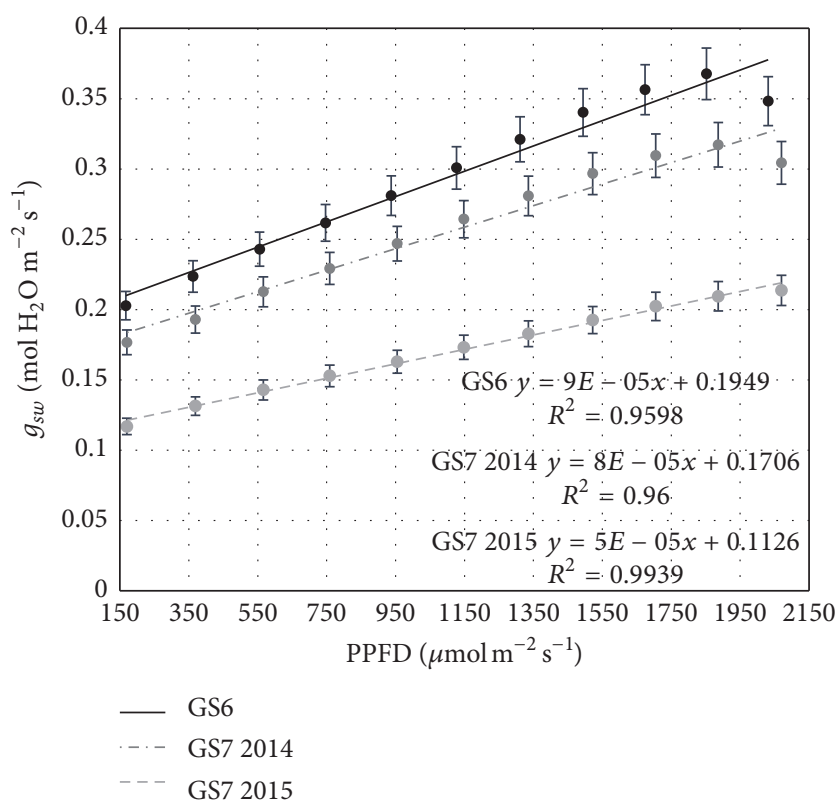

Figure 3: Mean Flag Leaf $g_{s}$ at Growth Stage 6 and Growth Stage 7 in 2014 and 2015 of grain sorghum at decreasing PPFD grown on a Tunica clay soil near Elizabeth, MS, at three levels of added $\mathrm{N}$-fertilizer $\left(0,112\right.$, and $\left.224 \mathrm{~kg} \mathrm{~N} \mathrm{ha}^{-1}\right)$. Means for GS6 are of three plants, two hybrids (83P17 and DKS54-03), two years, and three Nfertility treatments. For GS7 means are separated by year. Mean error bars set at $P \leq 0.05$.

2014. Both curves for $g_{s}$ at GS7 in 2014 and 2015 were linear (Figure 3). However $g_{s}$ in 2015 was only $65 \%$ to $70 \%$ of the rates observed at all PPFDs in 2014 further indicating drought stress occurred in 2015 and thus not as free of an exchange of $\mathrm{CO}_{2}$ and $\mathrm{H}_{2} \mathrm{O}$ vapor between the intercellular spaces of the leaves and the atmosphere due to smaller stomatal apertures. This also helps to partially explain the reduced levels of $A$ previously discussed.

Similar to what was observed with $g_{s}$, no differences in $E_{m}$ at GS6 across PPFD levels were observed among N-fertility rates, hybrids, years nor their interactions. Again a linear formula best fits the $E_{m}$ data (Figure 4). The rates of $E_{m}$ at GS7 were not different between hybrids, $\mathrm{N}$-fertility rates, or its interactions in relation to PPFD levels. Transpiration rates at GS7 though did differ significantly $(P \leq 0.05)$ between years while the interaction year $\times$ PPFD level was not statistically significant. Data for $E_{m}$ at GS7, like that at GS6, was linear in both years with respect to its response to decreasing PPFD levels (Figure 4). The lower transpiration rates in 2015 compared to 2014 are most likely due to less available soil water due to the lack of rainfall and sufficient irrigation as is evident from the environmental data previously discussed. Grain sorghum like all plant species is not immune to drought stress. Its reputation for drought tolerance is based primarily on the plant's responses to such stress prior to reproductive growth. These data on $E_{m}$ further point to the likelihood of plants in 2015 experiencing drought stress during kernel filling. Transpiration rates at GS6 and both years at GS7 were positively associated with the respective $g_{s}$ levels (Figure 5).

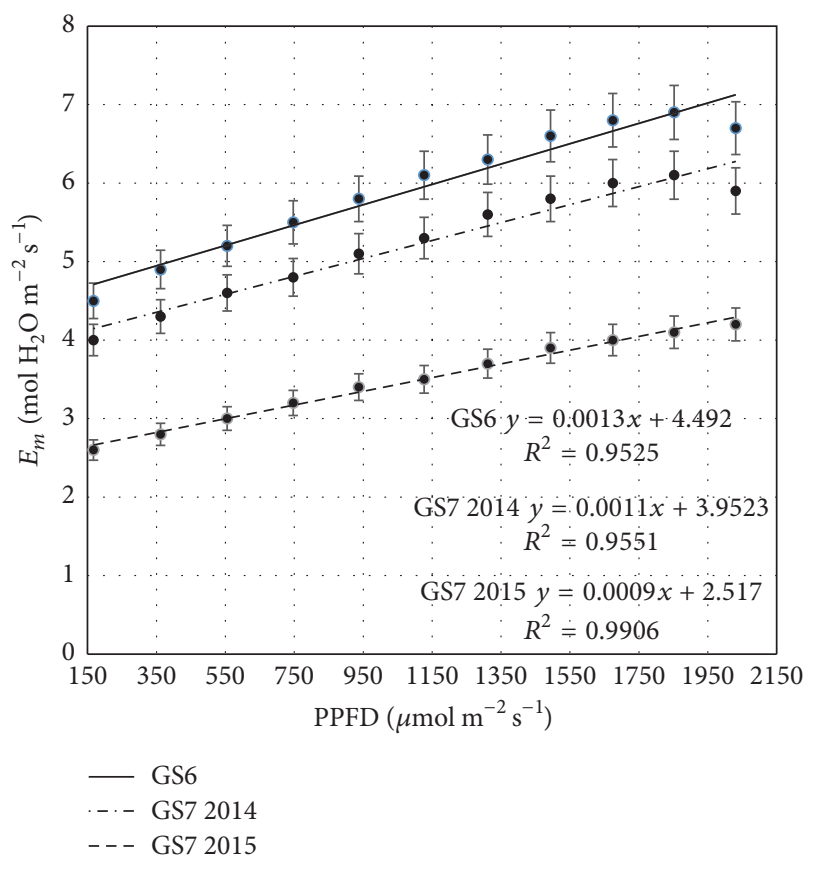

Figure 4: Mean Flag Leaf $E_{m}$ at Growth Stage 6 and Growth Stage 7 in 2014 and 2015 of grain sorghum at decreasing PPFD grown on a Tunica clay soil near Elizabeth, MS, at three levels of added $\mathrm{N}$-fertilizer $\left(0,112\right.$, and $\left.224 \mathrm{~kg} \mathrm{~N} \mathrm{ha}^{-1}\right)$. Means for GS6 are of three plants, two hybrids (83P17 and DKS54-03), two years, and three Nfertility treatments. For GS7 means are separated by year. Mean error bars set at $P \leq 0.05$.

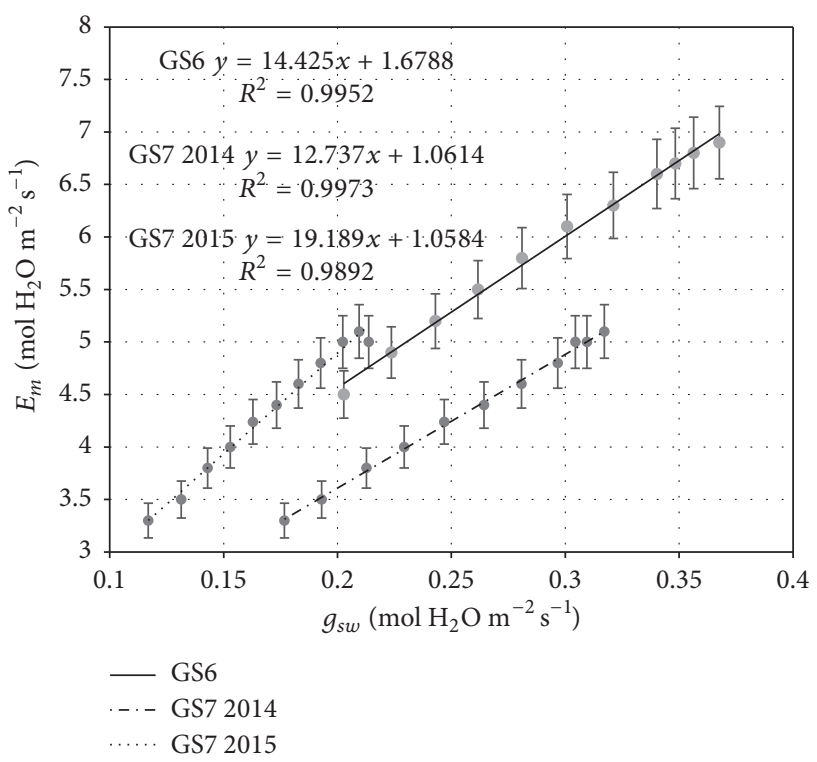

FIGURE 5: Ratio of $E_{m}$ to $g_{s}$ at Growth Stages 6 and 7 of grain sorghum grown on a Tunica clay soil near Elizabeth, MS, at three levels of added $\mathrm{N}$-fertilizer $\left(0,112\right.$, and $\left.224 \mathrm{~kg} \mathrm{~N} \mathrm{ha}^{-1}\right)$ with decreasing PPFD. For GS6 means are of three plants, two hybrids (83P17 and DKS54-03), two years (2014 and 2015), and three Nfertility treatments. For GS7 means are separated by year. Mean error bars set at $P \leq 0.05$. 


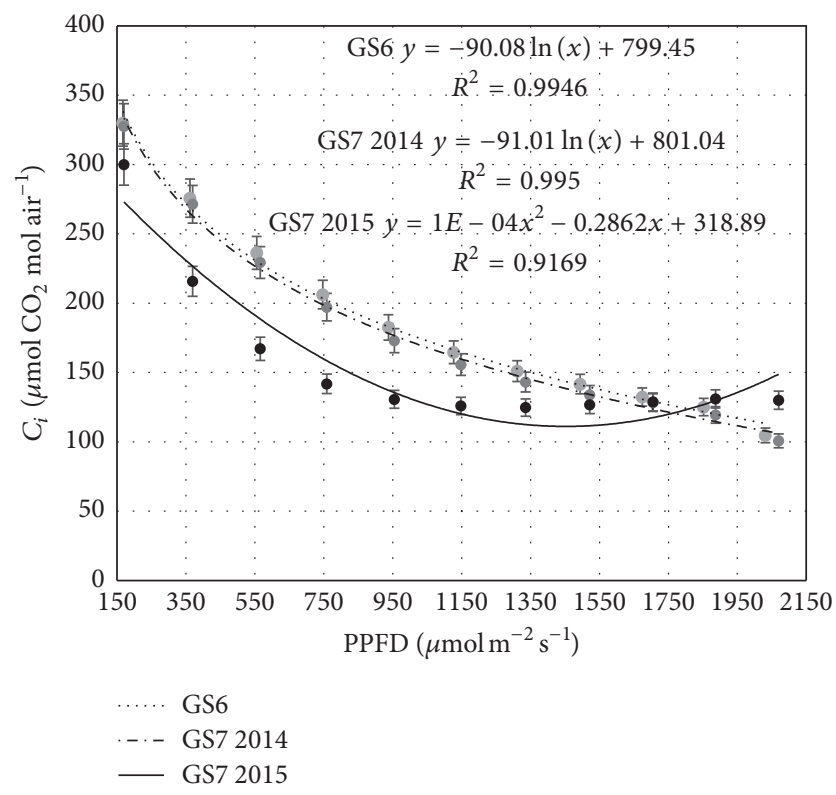

Figure 6: Mean $C_{i}$ at Growth Stages 6 and 7 of grain sorghum in response to decreasing PPFD grown on a Tunica clay soil at three levels of added N-fertilizer near Elizabeth, MS. At GS6 means are of three plants, two hybrids (83P17 and DKS54-03), two years (2014 and 2015), and three $\mathrm{N}$-fertility levels $\left(0,112\right.$, and $\left.224 \mathrm{~kg} \mathrm{~N} \mathrm{ha}^{-1}\right)$. At GS7 years are reported separately. Mean error bars set at $P \leq 0.05$.

Liner relations were observed in all cases with $R^{2} \geq 0.98$. These results are similar to those previously reported for corn [16].

The rate of increase in $C_{i}$ as PPFD was decreased was best expressed as a log linear response for both GS6 and GS7 in 2014 (Figure 6). At the lowest indicated PPFD of $\leq 200 \mu \mathrm{mol} \mathrm{m}^{-2} \mathrm{~s}^{-1}, C_{i}$ was approximately $93 \%$ of the preset $\mathrm{CO}_{2}$ level of $355 \mu \mathrm{mol} \mathrm{mol}^{-1}$ indicating photosynthesis had nearly ceased. At PPFD levels $\leq 1200 \mu \mathrm{mol} \mathrm{m}^{-2} \mathrm{~s}^{-1}, C_{i}$ appeared to increase at a greater rate than at PPFD levels $\geq 1200 \mu \mathrm{mol} \mathrm{m}^{-2} \mathrm{~s}^{-1}$, indicating that $A$ declines at a slightly faster rate than stomatal closure as PPFD levels decrease. Data on $C_{i}$ did not change in 2015 at GS7 as PPFDs decreased from an indicated level of 2200 to $1000 \mu \mathrm{mol} \mathrm{m}^{-2} \mathrm{~s}^{-1}(y=1.0 E-$ $\left.0.4 x^{2}-0.2562 x+318.89\right)$, compared to the log linear change in $C_{i}$ noted in 2014 for GS7 through the entire spectrum of PPFDs. This further demonstrates $A$ at GS7 in 2015 was being limited and not as responsive to higher PPFD levels as were plants in 2014. The changes observed in $C_{i}$ with decreases in PPFD do not fit the popular "Ball-Berry" model of $g_{s}$, which assumes the $C_{i}$ /atmospheric $\left[\mathrm{CO}_{2}\right]$ ratio to be constant and linear [17]. However, the observed response may be related to the comparatively short time spent in acquiring these data at individual PPFD levels as to what was spent in other reported studies.

Intrinsic water use efficiency (IWUE) defined by Farquhar and Sharkey [18] as the ratio of a unit of $\mathrm{CO}_{2}$ fixed by photosynthesis $(A)$ to an equivalent unit of stomatal conductance $\left(g_{s} * 100\right)$ was noted for both years at GS6 and at GS7 in 2014 declined as indicated PPFD was reduced

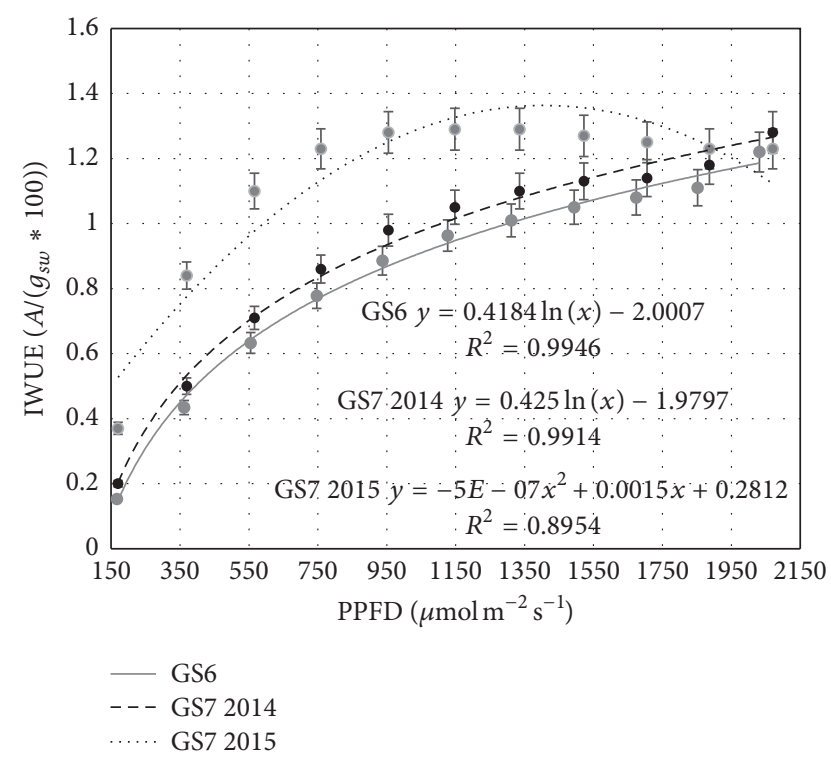

FIGURE 7: Mean intrinsic water use efficiency at Growth Stages 6 and 7 of grain sorghum in response to decreasing PPFD grown on a Tunica clay soil at three levels of added $\mathrm{N}$-fertilizer near Elizabeth, MS. At GS6 means are of three plants, two hybrids (83P17 and DKS54-03), two years (2014 \& 2015), and N-fertilizer levels of 0, 112, and $224 \mathrm{~kg} \mathrm{~N} \mathrm{ha}^{-1}$. Data for GS7 are separated by year. Mean error bars set at $P \leq 0.05$.

from 2200 to $\simeq 1000 \mu \mathrm{mol} \mathrm{m}^{-2} \mathrm{~s}^{-1}$, where a $1: 1$ ratio of $A$ to $g_{s}$ occurred at GS6 and GS7 in 2014 (Figure 7). A further decrease in PPFD resulted in a more rapid decline in IWUE. This decline in IWUE at the PPFD levels used in this experiment for both years at GS6 and GS7 in 2014 is best defined by a $\log$ linear relationship. The more rapid decline of IWUE below $1000 \mu \mathrm{mol} \mathrm{m}^{-2} \mathrm{~s}^{-1}$ indicated PPFD shows that the decrease in $A$ with declining PPFD is slightly more rapid than the rate of stomatal closure with decreasing light levels similar to what was noted in $C_{i}$ data.

Data on IWUE from GS7 2015 on the other hand did not have a log linear relationship (Figure 7). Basically in 2015 there was a linear trend for IWUE from 2200 to $800 \mu \mathrm{mol} \mathrm{m}^{-2} \mathrm{~s}^{-1}$ indicated PPFD, after which the ratio rapidly declined to $A:\left(g_{s} * 100\right)=0.37$. The greatly reduced levels of $A$ at $\geq 800 \mu \mathrm{mol} \mathrm{m}^{-2} \mathrm{~s}^{-1}$ PPFD along with lower $g_{s}$ in 2015 at GS7 combined to produce these unusual levels of IWUE compared to the other data. The GS7 2015 data though support the conclusion that drought and possibly heat stress negatively affect $\mathrm{CO}_{2}$ fixation in grain sorghum like in other crop species. Farquhar and Sharkey [18] in an extensive literature review concluded that stomata functioned more to regulate water loss and only marginally limit $A$. The apparent lag in $g_{s}$ of this experiment appears to support that conclusion.

No attempt was made to correlate grain yields with $A$ levels or other physiological parameters observed in this experiment. Not only did nitrogen fertility levels have no statistical impact upon $A$ or stomatal function but grain yields in 2014 were unaffected (data not shown) and only 
the $224 \mathrm{~kg} \mathrm{Nha}^{-1}$ treatment in 2015 had a greater yield $\left(3627 \mathrm{~kg} \mathrm{ha}^{-1}\right)$ than the lower $\mathrm{N}$ rate $\left(3025 \mathrm{~kg} \mathrm{ha}^{-1}\right)$ and the control $\left(2882 \mathrm{~kg} \mathrm{ha}^{-1}\right)$ which were not statistically different $\left(\right.$ lsmeans $_{0.05}$ ) from each other. Similar findings of a lack of a relationship of $A$ to yield have been reported in a number of studies with different crop species, despite the fact that total phytomass and economic yield are largely the end products of a season's worth of $A$.

\section{Abbreviations}

$\begin{array}{ll}A: & \text { Net assimilation rate, } \mu \text { mols } \mathrm{CO}_{2} \mathrm{~m}^{-2} \text { leaf area } \mathrm{s}^{-1} \\ g_{s}: & \text { Stomatal conductance, } \mathrm{mol} \mathrm{H}_{2} \mathrm{O} \mathrm{m}^{-2} \mathrm{~s}^{-1}\end{array}$

$E_{m}: \quad$ Transpiration rate, $\mathrm{mol} \mathrm{H}_{2} \mathrm{O} \mathrm{m}^{-2} \mathrm{~s}^{-1}$

$C_{i}$ : Intercellular $\left[\mathrm{CO}_{2}\right], \mu \mathrm{mol} \mathrm{CO} \mathrm{mol} \mathrm{air}^{-1}$

IWUE: Intrinsic water use efficiency, $A /\left(g_{s} * 100\right)$

PPFD: Photosynthetic photon flux density, $\mu \mathrm{mol} \mathrm{m}{ }^{-2} \mathrm{~s}^{-1}$

GS: $\quad$ Growth stage

GDU 10: Growing degree units at base $10^{\circ} \mathrm{C}$.

\section{Disclosure}

Trade names are used in this publication solely for the purpose of providing specific information. Mention of a trade name, propriety product, or specific equipment does not constitute a guarantee or warranty by the USDA-ARS and does not imply approval of the named product to the exclusion of other similar products.

\section{Competing Interests}

The author declares there are no competing interests regarding the procedures used or data presented for publication of this manuscript.

\section{References}

[1] USDA-NASS, "USDA-National Agriculture Statistics Service Quick Stats," 2016, http://quickstats.nass.usda.gov.

[2] H. A. Bruns, "Irrigation, seeding rates, and row type effects on grain sorghum in the Midsouth," Agronomy Journal, vol. 107, no. 1, pp. 9-12, 2015.

[3] L. G. Heatherly, R. A. Wesley, and C. D. Elmore, "Corn, sorghum, and soybean response to irrigation in the Mississippi River alluvial plain," Crop Science, vol. 30, pp. 665-672, 2001.

[4] R. A. Wesley, C. D. Elmore, and S. R. Spurlock, "Deep tillage and crop rotation effects on cotton, soybean, and grain sorghum on clayey soils," Agronomy Journal, vol. 93, no. 1, pp. 170-178, 2001.

[5] M. D. Hatch and C. R. Slack, "C4 photosynthesis: discovery, resolution, recognition and significance," in Discoveries in Plant Biology, S.-D. Kung and S.-F. Yang, Eds., pp. 175-196, World Scientific Publishing, Academia Sinica, Taipei, China, 1998.

[6] V. B. Subramanian, S. Venkateswarlu, M. Maheswari, and M. N. Reddy, "Influence of solar radiation and vapour pressure deficit on transpiration efficiency of rainfed sorghum," Journal of Agronomy and Crop Science, vol. 171, no. 5, pp. 336-342, 1993.

[7] P. V. V. Prasad and M. Djanaguiraman, "High night temperature decreases leaf photosynthesis and pollen function in grain sorghum," Functional Plant Biology, vol. 38, no. 12, pp. 993-1003, 2011.

[8] P. A. Fay and A. K. Knapp, "Stomatal and photosynthetic responses to shade in sorghum, soybean and eastern gamagrass," Physiologia Plantarum, vol. 94, no. 4, pp. 613-620, 1995.

[9] R. L. Vanderlip and H. E. Reeves, "Growth stages of sorghum [Sorghum bicolor, (L.) Moench.] ", Agronomy Journal, vol. 64, no. 1, pp. 13-16, 1972.

[10] B. R. Golden and L. Oldham, Nitrogen Fertility, MSUCares, Mississippi State University Extension, Starkville, Miss, USA, 2016, https://msucares.com/agriculture/crops/soils/nitrogenfertility.

[11] Mississippi State University Extension Service (MSUES), Delta Agricultural Weather Center, Mississippi State University, Starkville, Miss, USA, 2016, http://www.deltaweather.msstate .edu.

[12] S. B. Idso and D. G. Baker, "Method for calculating the photosynthetic response of a crop to light intensity and leaf temperature by an energy flow analysis of the meteorological parameters," Agronomy Journal, vol. 59, no. 1, pp. 13-21, 1967.

[13] S. B. Idso and D. G. Baker, "The naturally varying energy environment and its effects upon net photosynthesis," Ecology, vol. 49, no. 2, pp. 311-316, 1968.

[14] J. M. Bremner and K. Shaw, "Denitrification in soil. II. factors affecting denitrification," The Journal of Agricultural Science, vol. 51, no. 1, pp. 40-52, 1958.

[15] S. Peng, D. R. Krieg, and F. S. Girma, "Leaf photosynthetic rate is correlated with biomass and grain production in grain sorghum lines," Photosynthesis Research, vol. 28, no. 1, pp. 1-7, 1991.

[16] H. A. Bruns, "Ear leaf photosynthesis and related parameters of transgenic and non-GMO maize hybrids," International Journal of Agronomy, vol. 2015, Article ID 731351, 5 pages, 2015.

[17] J. T. Ball, I. E. Woodrow, and J. A. Berry, "A model predicting stomatal conductance and its contribution to the control of photosynthesis under different environmental conditions," in Progress in Photosynthesis Research, Proceedings of the 7th International Congress on Photosynthesis, J. Biggins, Ed., vol. 4, pp. 221-224, Martins Nijhoff, Dordrecht, The Netherlands, 1987.

[18] G. D. Farquhar and T. D. Sharkey, "Stomatal conductance and photosynthesis," Annual Review of Plant Physiology, vol. 33, no. 1, pp. 317-345, 1982. 


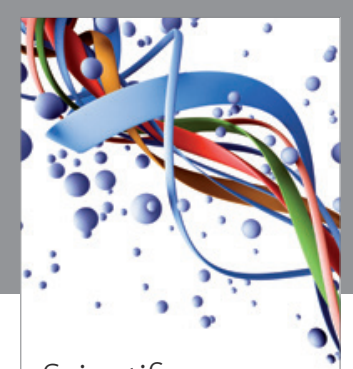

Scientifica
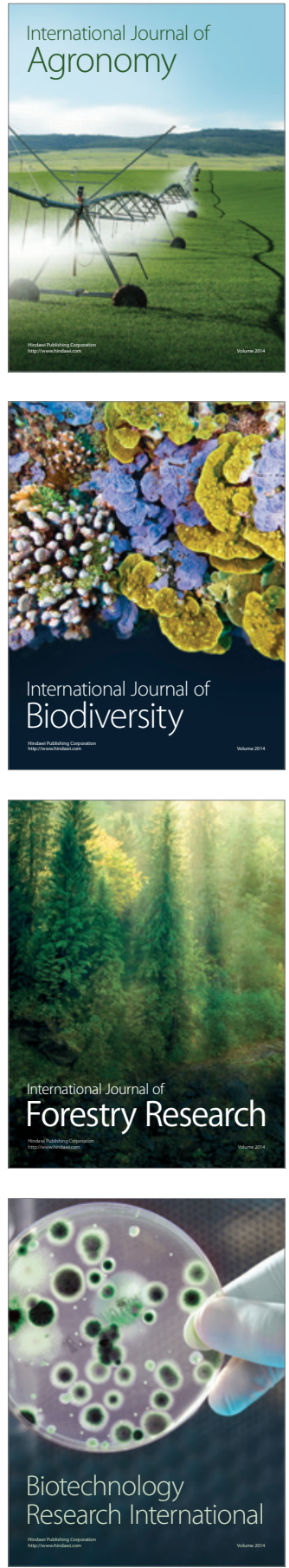
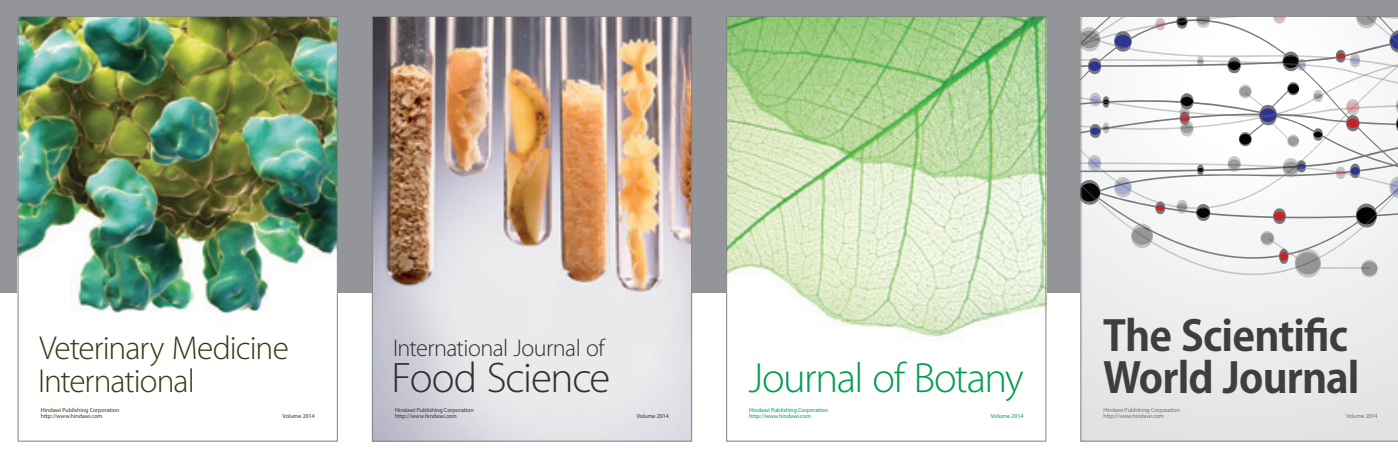

The Scientific

\section{World Journal}

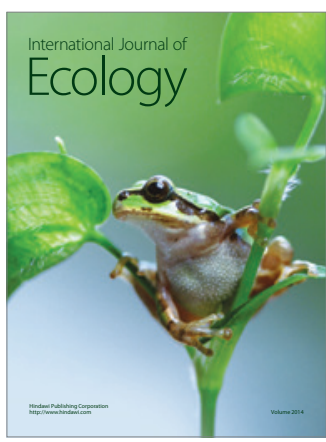

\section{Hindawi}

Submit your manuscripts at

http://www.hindawi.com
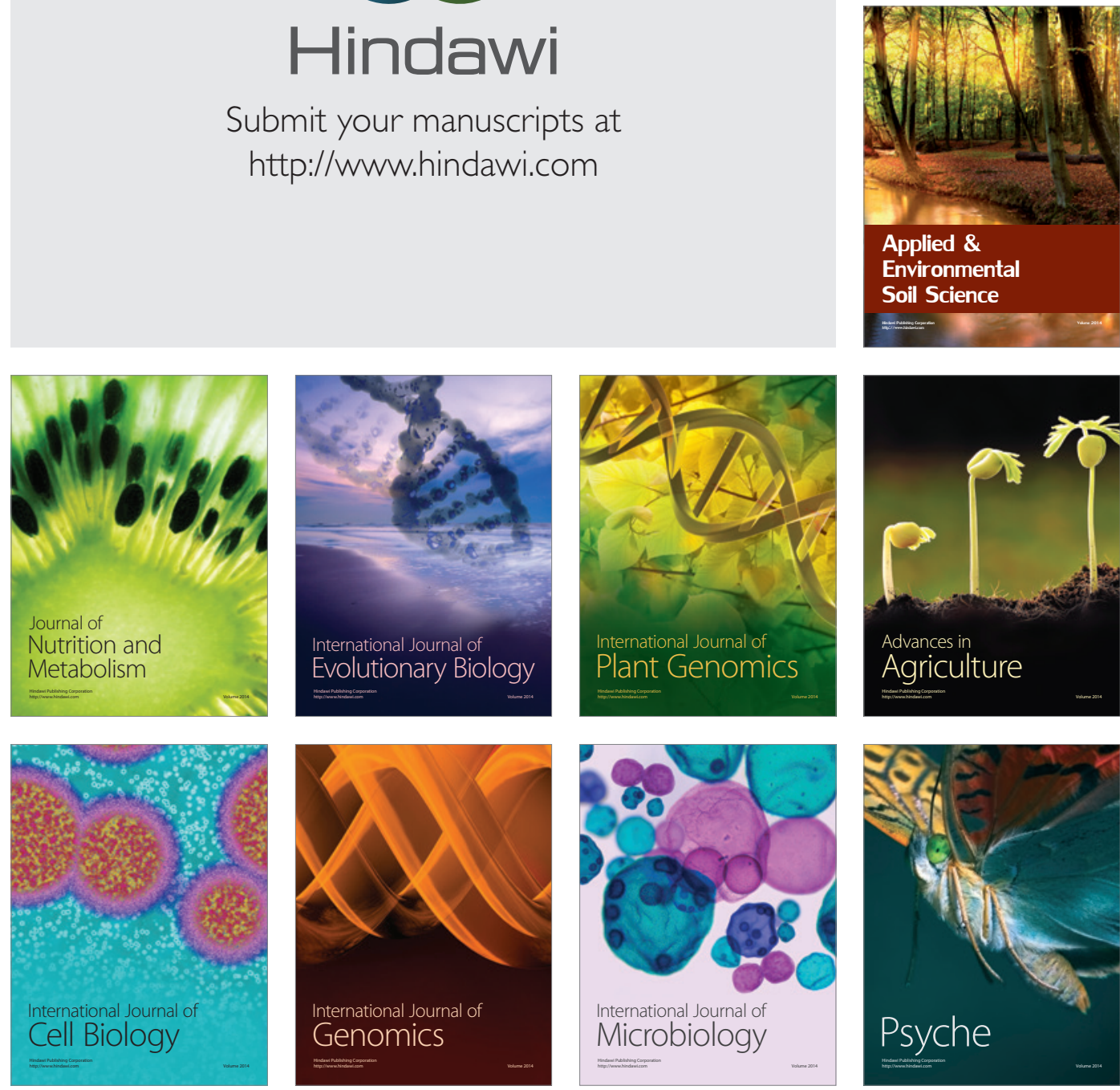
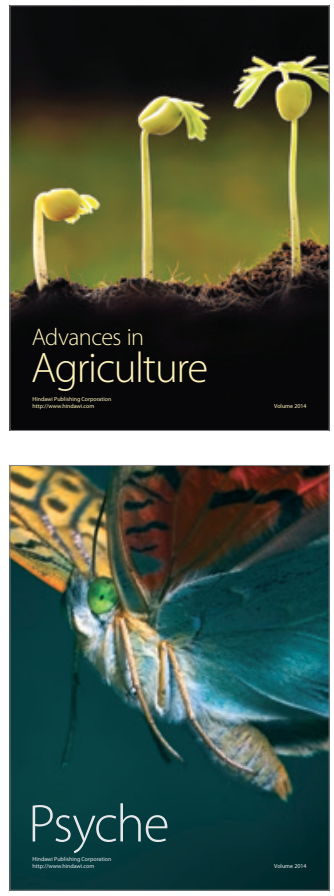